\title{
On problem-oriented policing: the Stockholm lecture
}

\author{
Herman Goldstein ${ }^{*}$
}

\begin{abstract}
This paper is an edited version of the speech given upon being awarded the 2018 Stockholm Prize in Criminology. After a brief introduction, the paper describes the concept of problem-oriented policing (POP), first proposed in 1979. It goes on to assess the extent to which the police have adopted POP, and its current status. POP is, in the immediate sense, aimed at a reduction in the incidence or severity of the problem on which attention is focused, and, in the broader sense, at improving the fundamentals of policing in a democratic society.
\end{abstract}

Keywords: Crime analysis, Crime reduction, Implementation, Problem-oriented policing, Problem-soloving

\section{Background}

The award of the 2018 Stockholm Prize for Criminology is significant for recognizing the progress in building stronger bridges between the fields of criminology and policing.

I welcome the new relationships that have been established in recent years and will seek, in my comments, to highlight a few of the developments in problem-oriented policing (POP) that contribute to strengthening those relationships. ${ }^{1}$ It is a personal reflection of working in this field for over six decades.

By virtue of their sensitive function, the police are often in the limelight. That has been especially true in the United States in the past several years, where police have drawn intensive attention, often prompted by their use of deadly force; by charges of abuse and corruption; and by allegations of unequal treatment of people of color (President's Task Force 2015). Such concerns raise deep issues that connect with the very fabric of our society: the relationship of government to its citizens; the use of coercive force; and the dignity, rights and freedom of each citizen. These issues are of the utmost importance, and they properly evoke strong reactions about policing. But beneath them lie the foundational issues relating to how societies can best meet the unique needs for policing. Filling these needs is infinitely more complex than the

*Correspondence: hgold@wisc.edu

University of Wisconsin, Madison, USA general public commonly recognizes (Goldstein 1977). POP helps to meet these needs by working intensively in a very detailed and clinical way to improve the end products of policing, but simultaneously, by contributing, through that work, to refining the institution of policing itself. The ultimate goal is to equip officers working within a refined institution to be better equipped to meet the sensitive needs of a multi-cultural and democratic society.

\section{The concept in brief}

To move in this direction, I proposed a new paradigm for reforming the police (Goldstein 1979, 1990). I argued that-in seeking to improve policing-more attention be focused on the substance of policing-on the outcomes of police efforts to deal with the specific problems that comprise their business. I labeled the paradigm "POP". It called for the police:

- To identify specific problems the public expected them to handle;

- To dig deeply into understanding each problem; and

- To think freshly and creatively about the best possible tailor-made response.

\footnotetext{
1 This article is the modified text of Professor Herman Goldstein's lecture delivered in Stockholm, Sweden, on 13 June 2018 when he received the Stockholm Prize in Criminology.
} 
As the police searched for that response, they were urged to place a high value:

- On preventive action;

- On responses that preferably do not depend wholly on the criminal justice system; and

- On alternatives that engaged the community, other public agencies, and members of the private sector having a direct interest in the problem.

The process then called for implementing the agreedupon response. And the final step called for a strong commitment to assessing the impact of that response, particularly for its effectiveness and fairness.

I hoped that each police agency would, because of the intensive effort involved, address just one or a few problems, but that their collective results-appropriately sharedwould benefit all, and ultimately contribute to a steadily growing body of knowledge to guide police practices and policies. The problems addressed soon began to accumulate: from curbing bullying in schools to restoring neighborhoods; from controlling graffiti to reducing the financial frauds that harass the elderly; from lowering robberies at ATMs to addressing human trafficking; and from controlling panhandling to reducing deaths in accidents involving motorcycles. These cases reflect the extraordinary range of tasks police are called on to handle-and, correspondingly, the enormous challenge each one of them presents.

\section{Problem-oriented policing: Progress and current status}

When such an idea is launched, it is extraordinarily difficult to track its diffusion, to measure its impact, or to gauge its overall effectiveness (see Leigh et al. 1996, 1998; Scott, 2000; Weisburd et al. 2010). Predictably, many early initiatives reflected good intentions, but often lacked a fundamental understanding of the concept (Braga and Weisburd 2006). As understanding has improved and other advancements have been made (such as computing, mapping and analysts' training) the concept has spread, taking different forms, and moving in different directions. It has been implemented in other settings, such as in federal regulatory agencies (Sparrow 2000) and in natural resource management (Sparrow 2008). Some elements of the concept are reflected in the movements to establish problem-solving courts (see for e.g. Berman and Feinblatt 2005; Wolf 2007) and community prosecution programs (see Coles and Kelling 1999; Dickey and McGarry 2005).

Initially, I did not adequately acknowledge the importance of having enough individuals with the appropriate research and assessment skills available to work with the police. This has been a major impediment in advancing the concept. In the earliest days, a number of different entities stepped in to fill the void. Police received the guidance of skilled researchers associated with the organizations that promoted the experiments (Goldstein and Susmilch 1982; Eck and Spelman 1987). Several agencies established relationships with university-based researchers, some of which have endured to this day. Several agencies borrowed the analytical staff of the umbrella agencies of which they were a part. And in 2003, Ron Clarke and John Eck, with the support of the UCL Jill Dando Institute of Crime Science, helped enormously by publishing a manual on how to become a problem-solving analyst (Clarke and Eck 2003). The manual proved to be so popular, it has since been translated into seventeen other languages (see http://www.popcenter.org).

Since then, several new steps have been taken to help meet the need. Colleges are producing, and police agencies are hiring, more analysts who are increasingly better equipped to engage in the necessary analysis. That does not guarantee they will be used for that purpose (Boba 2003). Much depends on the priorities of management. But, as one indication of success, it is now common for those teams of problem-solvers, whose efforts rise to the top and draw international recognition, to have, among their members, someone well versed in rigorously analyzing problems and in assessing the impact of new responses applied to them.

Most encouraging has been the substantial expansion of programs in several departments of criminology to train students at both undergraduate and graduate level in analytical skills. This has gained further momentum with the development of evidence-based policing-with its emphasis on more rigorous evaluation of policing strategies and the use of scientific methods in the evaluation of research for use in police practice (Sherman 2015). With the mix of these new investments and various approaches, we are on the way to establishing much stronger links among academic research, the training of students, the preparation of graduate students, and the maintenance of strong two-way relationships with analysts and practitioners in the field. Taken together, these connections will help to develop and refine the concept of POP and will help, more broadly, to elevate the thoughtprocesses that the police institution needs.

We recognized, early on, that if POP was to succeed, it was essential that an entity be created to collect and analyze the work done under this rubric, and to help guide agencies and individual officers in advancing their efforts. Those needs have been superbly met by the Center for POP, established in 2002. It has had the strong leadership of Michael Scott, a former police executive and now a university professor, and Ron Clarke and Graeme Newman, both criminologists. The Center, now housed at 
Arizona State University, has, through its archival, analytical and dissemination roles, produced a wealth of material, easily accessible on the web and in printed form (see http://www.popcenter.org). Its many publications now include guides on responding to over 70 specific problems. It also serves as a repository for the submissions to the annual International Goldstein Award for POP and the UK equivalent-the Tilley Award. Both schemes encourage entries from the police and similar agencies of problem solving projects, with the Goldstein Awards running from 1993.

Police officers of all ranks have direct access to this material, as do researchers, journalists, and community activists. Through its sponsorship of the annual POP conference, the Center provides a highly-respected forum in which practitioners and researchers gather to share the results of their latest problem-solving-serving as a vehicle for showcasing and steadily elevating the quality of work being done in the field. ${ }^{2}$

Despite these gains, I have grown accustomed to viewing successful efforts to implement POP-when carried out in all of its full dimensions-as episodic rather than systematic; as the results of relatively isolated cells of initiative, energy and competence. I view these pockets of achievement as exciting and pointing the way but sprinkled among a vast sea of police operations that remain traditional and familiar. So I feel the need, especially in the current climate in the United States, to guard against exaggerating what is being achieved in POP, especially when related to the magnitude of the still unmet needs in policing. But reenergized by the Stockholm award and its associated conference, I find my own confidence in the concept renewed, inspiring me to build on it and to focus on its potential for the future.

\section{Advances beyond achieving better outcomes}

I am especially encouraged by the number of successful POP case studies leading to eliminating or reducing a variety of behavioral problems (see http://www.popce nter.org). They have appropriately focused on outcomes.

Given my career-long interests in the institution of policing, I thought it appropriate to draw attention to a different dimension of the body of work accomplished to date. As I have already noted, in formulating POP, I had hoped from the very outset that work on improving outcomes would be a vehicle for stimulating and facilitating changes in the institution of policing. It is

\footnotetext{
${ }^{2}$ Editor's note: A recent review of the Goldstein submissions from 1993 to 2017 (Schnobrich-Davis et al. 2018) concluded that there has been 'significant progress in the development of problem-solving and its continuation as a practice within police agencies' (page 12), with increased use of partners in helping to deliver appropriate responses to crime and public safety problems.
}

an extraordinarily important goal. As the police institution is currently shaped, it frequently impedes innovative approaches in policing that seek to improve outcomes. I'd like to identify some indications that this goal of bringing about change in the institution is beginning to be realized. It is a dimension of our work that is less frequently recognized.

In focusing on the institution, I emphasize I am not focusing on the actions of individual officers. Repeating a conclusion I reached years ago, the police institution, at least in the United States, is seriously flawed. A number of factors curtail its capacity to respond more fully and appropriately to the problems that the public expects it to handle. Its function is poorly defined. It is vulnerable to being burdened with additional responsibilities as the agency of last resort, operating $24 \mathrm{~h}$ a day and expected to respond to each call or message. It is poorly understood by the public. It is rarely provided the resources, authority and skills required to fulfill the wide range of tasks expected of it. Consequently, it routinely over-promises.

As a result, police agencies and individual officerscultivating, as they understandably do, an aura of efficiency, omnipotence and omnipresence-frequently fall victim to weaknesses inherent in the institution of which they are a part. I do not want to imply that these conditions are universal. But I invite you to reflect on the degree to which my observations have any relevance in your respective communities or countries.

Remedying this situation is obviously a slow process. Policing is a complex entity. But I believe we can identify some lines of progress emerging from work accomplished under the POP rubric that have enormous potential for refining and thereby strengthening the police institution. I'd like to describe four examples: (1) the move toward greater specificity in defining what it is police do; (2) the fuller engagement of police officers; (3) the development of new alternative strategies; and (4) the engagement of new entities in sharing the responsibility for public safety.

\section{The specificity achieved by focusing on micro-problems}

Problem-oriented policing calls for singling out and defining, in highly specific terms, the piece of police business on which they decide to focus. In doing so, the police working within the new model are helping to clarify the nature of the police function. The in-depth inquiry called for in exploring a problem can be arduous. The gradual acquisition of data and information alters and usually narrows the definition of the problem. Out of these studies, the descriptions that ultimately emerge tend to focus on a particular type of behavior, offender, victim, place, time period, or occasionally, a combination of these characteristics-but each study has the great value of narrowing the problem. An illustration of the blending of 
these typologies to achieve specificity would be defining a problem as follows: assaults outside bars in heavily patronized adult entertainment areas at closing times on weekends. Indeed, many POP initiatives over the years, including some of the Goldstein and Tilley Award winners, addressed just this sort of specific problem and resulted in some creative solutions, among them the control of glasses and bottles used as weapons; the banning of promotions and discounts on alcohol; arrangements for more expeditious transit away from the premises to avoid the gathering of potentially contentious groups; and the staggering and expansion of closing hours (some examples include: Calgary Police Service 1994; Merseyside Police 2001; Isle of Man Constabulary 2005; Miami Police Department 2011; Lancashire Constabulary 2010, 2013; Havering Community Safety Partnership 2015; Portland Police Bureau 2015).

The commitment to specificity requires and facilitates the police and others participating in a study of a discrete piece of police business to focus on the subtle differences between and among troubling forms of behaviorto probe in greater depth. It narrows the task of finding appropriate responses. And it provides a tighter, more common focus around which the participants involved in an inquiry can collaborate and bond, generating support for the implementation of their conclusions.

Greater specificity serves several broader goals as well. It helps dispel the widespread practice of defining the police function in generic, global terms, such as "fighting crime", "maintaining law and order", or "dealing with violence". That practice is especially common in public debates about various forms of misbehavior in our communities. The practice is of no use in channeling public discussion. And it is terribly misleading in its influence on applying resources to the problem, often resorting to the common response of simply assigning more personnel to the affected area. By using POP, the police are being more precise in labeling the problems they seek to address, thereby helping curb the public's tendency to resort to distortions in describing them, and opening the opportunity for bringing more creative, longer-lasting and more effective responses to bear on the specific problem.

The move to greater specificity also makes clear that, contrary to widespread impressions, police do much more than deal with crime. The micro-problems to which the police turn their attention most frequently do not involve criminal conduct. That serves as a reminder that the police spend most of their time on such matters as caring for people who cannot care for themselves; expediting the movement of people and vehicles; resolving conflicts; and providing a sense of greater security (American Bar Association 1980). Committed to using their new analytical framework, police apply it to all the problems that arise in these other areas in the same manner and with the same potential as they do in addressing problems that are defined as crimes.

The move to greater specificity helps to make clear that while "law enforcement" is commonly used as a synonym for policing, that usage of the term is misleading. Its use often leads to a great deal of confusion. "Law enforcement" is better understood as one of the means-albeit an especially important means-for responding to some of the problems with which the police must deal. It is not one of those problems. By not equating policing to law enforcement, the new paradigm helps place law enforcement in a more appropriate, less dominant perspective, thereby helping to clarify the nature of the police function.

\section{The engagement of rank-and file}

A second example of the potential for far-reaching institutional change brought about by POP relates to the engagement in the process-in the identification of problems, their study and the exploration of solutions-of officers at the lower levels in the police hierarchy (often referred to as the rank-and-file or as line officers). They have tended, largely by self-selection, to be officers who have an above-average understanding of the complex role of the police and a strong commitment to achieving equality, fairness and effectiveness in addressing problems. Their enthusiasm and leadership have not only produced results of great benefit to the recipients of police service, but have increased the job satisfaction of police officers and have benefited the institution of which they are a part.

Line officers can bring an enormous amount of unique experience and insight to rethinking how a problem is handled-drawn directly from their familiarity with how the problem manifests itself on the streets and in the homes on their beats. They are often in closer touch with the sentiments, perspectives, and resources of the communities being policed than are their superior officers. With the right kind of management support, they can often contribute new ideas for handling recurrent problems.

Locked into a semi-military-type organization that often discourages initiative, many of these officers have been frustrated by not having the freedom to deal with recurring problems, and to voice constructive ideas for dealing more effectively with them. They are commonly energized and empowered by their new opportunitiesespecially if a project to which they have contributed mitigates a long-standing problem. I've heard officers working in a problem-oriented mode proclaim that their experiences have been the highlights of their careers. 
Others have felt elated on being honored for their initiative and creativity by their agencies.

The most skilled of line officers attracted to engaging in POP have demonstrated a strong ability to collect data and to help refine and test the validity of their knowledge. Their greater involvement has increased their potential to contribute significantly to advancing the larger move to professionalizing the police. At POP conferences, for example, they become deeply immersed in discussing issues relating to the effectiveness and fairness of alternative methods for improving the police response to the common problems on which presentations are made.

This level of performance strongly challenges stereotypes and misconceptions about the role, characteristics and abilities of police officers. Despite all of the talk about the "police culture" (Manning and Van Maanen 1978), individual police officers are actually a very diverse lot. They differ widely in their personalities, their commitment, their perceptions of their job, and within recent decades, their levels of educational achievement. If we view POP as a novel approach to policing, we can see it as the vehicle that affords interested, talented and sophisticated officers the opportunity to broaden their skills, and it encourages their agencies to take advantage of their commitment and mental prowess.

Greater engagement of rank-and-file also challenges the common perception that police officers are automatons of sorts, empowered to enforce the law in a ministerial manner, but precluded from engaging in any considerations as to how the police are otherwise expected to act. Police officers must inevitably exercise discretion (Goldstein 1963; Davis 1975). Progressive agencies seek to equip their officers to use their discretion, and, at the same time, to help guide it to assure that their officers are operating within appropriate bounds. Their involvement with problem-solving is not only compatible with recognizing their more complex role, it helps groom officers to exercise their discretion in a responsible manner.

\section{The fuller use of a broader range of alternatives}

I'm especially encouraged by this third example of how POP contributes to strengthening the institution of policing. It has to do with efforts to seek out and implement new ways in which to respond to old problems. Police continue to suffer from the vestiges of an era in which they depended heavily on the criminal justice system as the primary vehicle for getting their job done. Much progress has been made in the past 50 years in developing a wide range of alternatives to enforcement, and much more attention is being given to prevention. But new challenges have arisen and, given the diverse problems police must handle, too many gaps remain.
Problem-oriented policing calls for breathing new momentum into this movement; to openly and aggressively develop a fuller range of alternatives specifically responsive to each problem (Goldstein 1990, pp. 102147). To the degree that police have turned to adopting preventive measures, they have, somewhat belatedly, turned to using the vast accumulation of research conducted by criminologists over the years that has great relevance to their work. I know better than to attempt to cite specific examples in that regard but I am compelled to make one exception. Drawn together by some overlaps in our work on situational crime prevention and POP, I had the good fortune to have collaborated with Ron Clarke in exploring the relationships between the two concepts in a project we conducted over a period of 2 years in cooperation with the Charlotte-Mecklenburg Police Department. It has pleased me that Ron's work on situational crime prevention-and the work of the many other environmental criminologists with whom I've had the pleasure of working over the years-is now being routinely employed by officers working in a problemoriented mode in fashioning their new responses to the problems on which they are focusing (Clarke and Goldstein 2002, 2003; see also Scott and Goldstein 2012).

Indeed, POP now gains much of its strength from drawing on such research. Thus, in one recent example, officers engaged in a project in Cincinnati, Ohio were persuaded by their own analysis and research that environmental conditions in an area of less than four city blocks were significant contributors to the gun violence occurring in the area (Cincinnati Police Department 2017). As a result, they took such varied actions as revising on-street parking restrictions, augmenting lighting, demolishing some properties, establishing a new recreational facility, and organizing the residents. This initiative was informed by criminological research on the linkages between criminal behaviors and the places around which they occur.

In citing these novel approaches, it is important to acknowledge that use of the criminal justice system has not been abandoned. Some problem-oriented projects reflect a blend of ties to criminological research, new initiatives, and the incorporation of some continued dependence on the system. The best example is also the most replicated POP project-initiated by David Kennedy, Anthony Braga, and their associates, working with the Boston police in the late 1990s (Braga et al. 2001). In contrast with the recent Cincinnati project, it focuses on offenders more directly, rather than the places around which their offending occurs. Concentrating initially on those engaged in gang violence, the approach has been expanded to seeking to deter a broader range of high-risk individuals. Now commonly 
referred to as focused deterrence, the replicated projects depend heavily on trying to help such individuals address troublesome life issues-such as substance abuse or lack of employable skills so that they might live lives free of criminal involvement. But the project continues to make use of the criminal justice system as a source of leverage (Kennedy 2008).

Regarding less serious offenders, and a broad range of common problems, the development of new responses has been fueled by the growing awareness of the limitations of the criminal justice system. Concerns are being increasingly expressed about its high costs, its limited value in achieving its objectives, and indications that it has become dysfunctional (Klingele et al. 2010). It is also severely criticized for having a disparate impact on minorities. This creates a new sense of urgency for designing an increased number of alternatives-for developing a better alignment between what is expected of the police and the means by which the police can meet those expectations.

Given the often stressful conditions under which the police currently operate, if a police officer, in current practice, is without an appropriate means for dealing with a problem, he or she must create an alternative. Individual police officers and their agencies have become very creative and effective at filling this need and often, much good is accomplished. But the circumstances are frequently more challenging and ambiguous. When that occurs, police are sometimes drawn to engaging in practices that are improper or clearly illegal. They may resort, for example, to making an arrest for some minor offense when an arrest would otherwise not be made; or make use of a delicate form of authority or strategy, such as stopping and frisking, in a questionable manner. Such improvisations have the potential for escalating a situation, resulting in a confrontation, and, as a result, increasing the potential for the need to use some degree of force.

These consequences arise to a much higher level of concern when the improvisations of individual officers are adopted as agency-wide practice and, most acutely, when they have a disparate and discriminatory impact on segments of the community. That, for example, has happened in the widespread misuse of stopping and questioning (La Vigne et al. 2014). By checking the alignment of current tasks and the means for dealing with them, POP can be an effective diagnostic tool for not only identifying practices gone awry, but for creating suitable alternatives.

\section{Engaging segments of the private sector to assume increased responsibility for public safety problems}

The fourth and final example I want to cite has enormous potential for redefining the function of the police. Studies conducted under POP are increasingly finding that another entity-in the private sector or in government-is able to reduce the magnitude of the problem, or even prevent it from occurring in the first instance. These findings mirror-and draw heavily upon-the accumulated research of criminologists, ranging from work on preventing crime through environmental design (Zahm 2007); the redesign of products in ways that prevent crime (Clarke and Newman 2005); and altering the management of places (Braga and Weisburd 2010).

Regarding the latter, for example, by adopting POP the police have intensified their efforts to work with landlords, merchants, motel owners, pharmacists, and school personnel-enlisting them in efforts to prevent problems arising on their premises. They use a variety of graded strategies, from seeking cooperation, to education, to persuasion. And if these somewhat subtle strategies fail, they resort, with appropriate evidentiary support, to using more coercive measures that are within their authority. For example, they may withdraw services, institute a charge for services, persuade legislators to enact regulations, or, in some instances, join with others in bringing a civil action.

We often refer to this process as the "shifting and sharing of responsibility for public safety." (Scott and Goldstein 2005). Now established as a routine strategy in the problem-oriented model, its use in a pro-active manner constitutes a fundamental change over past practices. The adoption of this approach has been emboldened in part by the new commitment, inherent in the model, to gathering data and the theoretical basis that supports their actions. Placed in a larger framework, these efforts hold the potential for contributing to a more rational approach to distributing the responsibility for public safety.

Complexities arise when, exhausting these strategies, police are left without the necessary support to press further; when economic or political interests put a ceiling on how far police can go in advocating for what may be, from the standpoint of the community and the police, a more sensible and equitable assumption of responsibilities. One of the most common current examples in the United States is in efforts by police, using the results of a substantial body of criminological research, to persuade merchants to alter their merchandising practices so as to minimize retail theft. Merchants frequently resist such suggestions, tethering police to arresting alleged offenders and processing them through the criminal justice system. This is at great financial cost to the police and the system, with questionable effectiveness in solving the problem and with sometimes disproportionate consequences for the alleged offenders and for the totality of the police function (Clarke and Petrossian 2012).

Problem-oriented policing has the potential for helping to address such complex situations. An in-depth study of 
a problem leads to more open examination. It gives the police a strong capacity to inform the situation through the collection and analysis of relevant carefully gathered data. It motivates and equips police leadership to take a more active, vocal role. It engages the community that ideally is a part of the study. Explorations of this nature are helped if the police bring to the table a strong commitment to acting as the representative of community interests, and also bring a reputation for being even-handed in exploring alternatives and in advancing new proposals.

The reluctance in the past of police leadership to press harder for a resolution of some of these stand-offs appears, in part, to stem from a sense that it is not their prerogative to do so. They may also feel that the political pressures against their doing so are too strong. But recently, some progressive police leaders have commendably taken a more aggressive stance-though in radically different contexts. In intra-governmental relations in the United States, a number of police chiefs are actively resisting pressures originating at the federal level to engage local police in the enforcement of federal immigration laws (Police Executive Research Forum 2012). The police have expressed concern not only for humanitarian reasons, but because their proposed involvement adversely affects their capacity to relate to immigrants and those who identify with and support them. Regarding the opioid epidemic, the leadership of American police appears to be of one mind in aggressively pressing the medical and pharmaceutical industries to tighten their control of addictive drugs. They are understandably concerned about the large number of lives lost, but police leadership is also concerned about the demand on their overtaxed resources (Police Executive Research Forum 2017). This new assertiveness is a welcome development.

It would be extraordinarily helpful if POP eventually leads, in the United States, to police leadership gradually moving to encourage and support research on some of the bigger problems they routinely handle-associated with alcohol, drugs, and especially firearms. And it would be helpful if leaders made use of the results of such research to recommend changes in public policies. Additionally, it would be useful, in the interests of perfecting the police institution, if the leadership of policing would more fully inform the public about the numerous ways in which these problems compound the complexity of policing. With the collection of data to which they have direct access, they are solidly equipped to do so.

\section{Conclusion}

I believe we have succeeded in establishing that POP is an effective means for channeling efforts toward improvement in policing. Integral to the concept is that such a focus on outcomes would, as a collateral benefit, bring about significant changes in the nature of the police institution. I have described a sampling of such changes that are materializing which I believe-along with other changes - if developed and multiplied-have the potential for bringing about much needed refinements. Having had this incentive to reflect anew on some of the accomplishments under POP, I see four major features inherent in the concept that are emerging with greater clarity and force.

\section{The first is that POP is principled}

The ultimate challenge in achieving effectiveness in the policing of a democracy is to do so within the constraints imposed on the use of police powers, but also in a manner consistent with the values of a free society. I refer to values such as equal treatment under the law; maximum respect for the dignity of each citizen; minimum use of coercive force; and gaining the consent of the governed. Police are expected to not only support these values, but to reinforce and extend them. That is what makes policing in a democracy so complex-and so demanding. Concern for these values is built into all decision-making in POP.

\section{The second is that POP is holistic}

It is a vehicle for updating the many interrelated pieces of the vast, complex machinery of policing that need adjustment to support quality policing. The concept provides the framework for refining the institution of policing-its function, organization, staffing, training-and their policies and practices affecting their consumers, the citizenry. No single thrust alone-be it the education of police personnel, efforts to engage the community, or the creation of specialized units - can be depended on to meet the most critical needs of the field. Each element in policing is better fashioned if designed, in an integrated manner, around a common commitment to elevating the effectiveness and fairness of responding to the specific problems that constitute police business.

\section{The third is that POP is built on being informed}

At every point, in the development of the concept, emphasis is placed on the need for solid information with which to support decision-making. POP challenges the simplistic characterizations of policing-the stereotypes, myths, and misunderstandings that have had an undue influence on so important and complex a function. In-depth studies are at the very core of addressing each problem. A high priority is attached to steadily increasing the quality of evaluations and to drawing on research in related fields to guide police practice. Police are encouraged to become 
as comfortable with the careful use of hard data, analysis, and accumulated research as they are with the requirement for precise use of evidence in investigating crimes. Ultimately, all of these efforts can help inform the many decisions and resolve the many conflicts that must be made in carrying out so complex an operation.

\section{The fourth is that POP is a continuing process}

The commitment to POP varies from time to time, and from place to place. But from among the many schemes for achieving reform in policing, it has survived and spread. And as a way of thought, elements of the concept are beginning to permeate previously unaffected aspects of policing. It is now connected with related fields of study, such as criminology. It is still evolving. It continues to emerge as a sensible, methodical and integrated framework for achieving positive change. I believe it does have the potential to meet the ultimate objective-to better equip police officers to meet the complex and sensitive needs of a multi-cultural and democratic society.

\section{Authors' contributions}

The author read and approved the final manuscript

\section{Acknowledgements}

Thanks to Gloria Laycock and Mike Scott for helping prepare this article.

\section{Competing interests}

The authors declare that they have no competing interests.

\section{Availability of data and materials}

Not applicable

\section{Funding}

Not applicable

\section{Publisher's Note}

Springer Nature remains neutral with regard to jurisdictional claims in published maps and institutional affiliations.

Received: 18 September 2018 Accepted: 5 October 2018

Published online: 26 October 2018

\section{References}

American Bar Association. (1980). ABA standards for criminal justice: Volume I, standards on the urban police function (2nd Ed.). Washington, D.C.: American Bar Association. https://www.americanbar.org/publications/ criminal_justice_section_archive/crimjust_standards_urbanpolice.html. Accessed 3 Aug 2018.

Berman, G., \& Feinblatt, J. (2005). Good courts: The case for problem-solving justice. New York: The New Press.

Boba, R. (2003). Problem analysis in policing. Washington, D.C.: Police Foundation and Office of Community Oriented Policing Services,

Braga, A. A., Kennedy, D. M., Waring, E. J., \& Piehl, A. M. (2001). Problem-oriented policing, deterrence, and youth violence: An evaluation of Boston's operation ceasefire. Journal of Research in Crime and Delinquency, 38(3), $195-225$
Braga, A., \& Weisburd, D. (2006). Critic: Problem-oriented policing: The disconnect between principles and practice. In D. Weisburd \& A. Braga (Eds.), Police innovation: Contrasting perspectives (pp. 133-152). Cambridge: Cambridge University Press.

Braga, A. A., \& Weisburd, D. L. (2010). Policing problem places: Crime hot spots and effective prevention. Oxford: Oxford University Press.

Calgary Police Service. (1994). Electric avenue: Taming an entertainment district. Submission to the herman goldstein award for excellence in problemoriented policing. http://www.popcenter.org/library/awards/golds tein/1994/94-03(W).pdf. Accessed 3 Aug 2018.

Cincinnati Police Department. (2017). P.I.V.O.T. Place-based investigations of violent offender territories: Submission to the herman goldstein award for excellence in problem-oriented policing.

Clarke, R. V., \& Eck, J. E. (2003). Becoming a problem-solving crime analyst: In 55 small steps. London: Jill Dando Institute of Crime Science. http://www. popcenter.org.

Clarke, R. V., \& Goldstein, H. (2002). Reducing theft at construction sites: Lessons from a problem-oriented project. In N. Tilley (Ed.), Analysis for crime prevention. Crime prevention studies (Vol. 13). Monsey, NY: Criminal Justice Press.

Clarke, R. V., \& Goldstein, H. (2003). Thefts from cars in center-city parking facilities: A case study in implementing problem-oriented policing. Crime Prevention Studies, 15, 257-298.

Clarke, R. V., \& Newman, G. R. (2005). Designing out crime from products and systems. Crime prevention studies (Vol. 18). Cullompton, U.K.: Willan Publishing.

Clarke, R. V., \& Petrossian, G. (2012). Shoplifting. Problem-oriented guides for police, problem-specific Guide No. 11 (2nd ed.). Washington: Office of Community Oriented Policing Services.

Coles, C., \& Kelling, G. (1999). Prevention through community prosecution. Public Interest, 136(Summer), 69-84.

Davis, K. C. (1975). Police discretion. St. Paul: West Publishing.

Dickey, W., \& McGarry, P. (2005). The search for justice and safety through community engagement: Community justice and community prosecution. Idaho Law Review, 42, 313-330.

Eck, J. E., \& Spelman, W. (1987). Problem-solving: Problem-oriented policing in newport news. Washington DC: Police Executive Research Forum.

Goldstein, H. (1963). Police discretion: The ideal versus the real. Public Administration Review, 23(3), 140-148.

Goldstein, H. (1977). Policing a free society. Cambridge, Mass: Ballinger Pub. Co. Univ. of Wisconsin Legal Studies Research Paper No. 1349. http://ssrn. com/abstract $=2596883$.

Goldstein, H. (1979). Improving policing: A problem-oriented approach. Crime \& Delinquency, 25(2), 236-258.

Goldstein, H. (1990). Problem-oriented policing. New York, NY: McGraw-Hill.

Goldstein, H., \& Susmilch, C. (1982). Experimenting with the problem-oriented approach to improving police service: A report and some reflections on two case studies. Photocopy of vol. 4 of the project on development of a problem-oriented approach to improving police service. Madison, Wis.: University of Wisconsin Law School. http://www.popcenter.org/library/ researcherprojects/DevelopmentofPOPVolIV.pdf. Accessed 3 Aug 2018.

Havering Community Safety Partnership. (2015). Safe and sound: Reducing violent crime in the night-time economy. Submission to the Herman Goldstein Award for Excellence in Problem-Oriented Policing.

Isle of Man Constabulary. (2005). Project centurion: Reducing crime and disorder on douglas promenade. Submission to the Herman Goldstein Award for Excellence in Problem-Oriented Policing. http://www.popcenter.org/libra ry/awards/goldstein/2005/05-05(W).pdf. Accessed 3 Aug 2018.

Kennedy, D. (2008). Deterrence and crime prevention: reconsidering the prospect of sanction. London: Routledge.

Klingele, C., Scott, M. S., \& Dickey, W. J. (2010). Reimagining criminal justice. Wisconsin Law Review 953

La Vigne, N. G., Lachman, P., Rao, S., \& Matthews, A. (2014). Stop and frisk: Balancing crime control with community relations. Washington, D.C.: Office of Community Oriented Policing Services.

Lancashire Constabulary. (2010). Smashing time-or not? Submission to the Herman Goldstein Award for Excellence in Problem-Oriented Policing.

Lancashire Constabulary. (2013). Nightsafe haven: Keeping you safe tonight. Submission to the Herman Goldstein Award for Excellence in ProblemOriented Policing. 
Leigh, A., Read, T., \& Tilley, N. (1996). Problem-oriented policing: Brit POP. Crime detection and prevention series, Paper No. 75. London: Home Office Police Research Group.

Leigh, A., Read, T., \& Tilley, N. (1998). Brit POP Il: Problem-oriented policing in practice. Police research series, Paper No. 93. London: Home Office Policing and Reducing Crime Unit.

Manning, P., \& Van Maanen, J. (1978). Policing: A view from the street. Santa Monica: Goodyear Publishing.

Merseyside Police. (2001). Operation crystal clear. Submission to the tilley award program. http://www.popcenter.org/library/awards/tilley/2001/01-49(Wcdrc).pdf. Accessed 3 Aug 2018.

Miami Police Department. (2011). Operation safe clubs: Enforcement and situational problem-oriented policing. Submission to the Herman Goldstein Award for Excellence in Problem-Oriented Policing. http://www.popcenter. org/library/awards/goldstein/2011/11-41(F).pdf. Accessed 3 Aug 2018.

Police Executive Research Forum. (2012). Voices from across the country: Local law enforcement officials discuss the challenges of immigration enforcement. Washington, D.C.: Police Executive Research Forum.

Police Executive Research Forum. (2017). The unprecedented opioid epidemic: As overdoses become a leading cause of death, police, sheriffs, and health agencies must step up their response. Washington, D.C.: Police Executive Research Forum.

Portland Police Bureau. (2015). Central precinct entertainment zone. Submission to the Herman Goldstein Award for Excellence in Problem-Oriented Policing.

President's Task Force on 21st Century Policing. (2015). Final report of the President's task force on 21st century policing. Washington, D.C.: Office of Community Oriented Policing Services.

Schnobrich-Davis, J., Block, S., \& Lupacchino, J. (2018). Analysis of Herman Goldstein problem-oriented policing awards from 1993 to 2017. Policing: A Journal of Policy and Practice. https://doi.org/10.1093/police/pay046.
Scott, M. S. (2000). Problem-oriented policing: reflections of the first twenty years. Washington DC: Department of Justice Office of Community-Oriented Policing Services.

Scott, M. S. \& Goldstein, H. (2005). Shifting and sharing responsibility for public safety problems. Problem-oriented guides for police response guide Series No. 3. http://www.popcenter.org/Responses/pdfs/shiftingsharing pdf. Accessed 22 July 2018

Scott, M., \& Goldstein, H. (2012). Ron Clarke's contribution to improving policing: A diffusion of benefits. In G. Farrell \& N. Tilley (Eds.), The reasoning criminologist: Essays in honor of Ronald V. Clarke (pp. 93-107). London: Routledge.

Sherman, L. W. (2015). A tipping point for 'Totally Evidence Based Policing': Ten ideas for building an evidence-based police agency. International Criminal Justice Review, 25(1), 11-29.

Sparrow, Malcolm K. (2000). The regulatory craft: Controlling risks, solving problems and managing compliance. Washington, DC: Brookings Institution Press.

Sparrow, Malcolm K. (2008). The character of harms: Operational challenges in control. Cambridge: Cambridge University Press.

Weisburd, D., Telep, C., Hinkle, J., \& Eck, J. E. (2010). Is Problem-oriented policing effective in reducing crime and disorder? Findings from a campbell systematic review. Criminology and Public Policy, 9(1), 139-172.

Wolf, R. (2007). Breaking with tradition: Introducing problem solving in traditional courts. New York: Center for Court Innovation.

Zahm, D. (2007). Using crime prevention through environmental design in problem solving. Problem-oriented guides for police, problem-solving tools. Washington, D.C.: Office of Community Oriented Policing Services.

\section{Submit your manuscript to a SpringerOpen ${ }^{\circ}$ journal and benefit from:}

- Convenient online submission

- Rigorous peer review

- Open access: articles freely available online

- High visibility within the field

- Retaining the copyright to your article

Submit your next manuscript at $\boldsymbol{\nabla}$ springeropen.com 